\title{
ŁUKASZ ANTOSIK*, JOANNA SŁOMSKA** \\ EARLY MEDIEVAL LOOMS IN POLAND IN THE LIGHT OF ARCHAEOLOGICAL FINDS
}

\begin{abstract}
The purpose of the paper is to present types of looms used in Poland in the Early Middle Ages in the light of archaeological finds. The basis for the source form parts of looms like loom weights and weaving tools. The authors present evidence discovered during excavations, beginning with the vertical warp-weighted loom through the horizontal pit loom to the foot loom. As established, the archaeological evidence discovered so far does not include construction fragments of other types of looms. Unfortunately, parts of looms are extremely rarely discovered. To obtain a more complete picture of looms functioning in the present-day Polish territory, the evidence is additionally extended by analogies from European territories, as well as iconography.
\end{abstract}

Keywords: loom, weaving, weaving tools, textile production, Early Middle Ages, Poland

In the course of excavations of early medieval sites dated from the $6^{\text {th }}$ to the mid- $8^{\text {th }}$ century, archaeologists often find artefacts that are interpreted as household tools. Among them are numerous elements related to the processing of textile materials. These are spindle whorls, spindles, weaving combs and weaving swords. ${ }^{1}$ It is far more rarely that the archaeologists discover remains of looms or at least their structural elements. Despite that, based on the collected evidence it can be stated that in the discussed period in Poland three types of looms were employed. ${ }^{2}$ As a result of the discussion initiated in Poland in the 1950s and 1960s that involved J. Kostrzewski, A. Nahlik and T. Wróblewski, it was established that the earliest loom which was in use was the vertical warp-weighted loom. ${ }^{3}$ The gradual process of replacement of this loom is dated to the Middle Ages, when the horizontal foot loom began to be universally used. It seems that the early medieval period functions as a bridge or transitory period when various types of weaving looms co-existed.

\footnotetext{
* Institute of Archaeology and Ethnology, Polish Academy of Sciences, Łódź; (D) https://orcid.org/0000-0003-4781-0476; 1.antos@wp.pl

** Institute of Archaeology and Ethnology, Polish Academy of Sciences, Łódź; (D) https://orcid.org/0000-0003-1920-4233; asia2499npm@gmail.com

${ }^{1}$ Bukowska-Gedigowa and Gediga 1986; Brzostowicz 2002; Dominiczak-Głowacka 2008, 243-270; Chudziak 2013, 171-184; Żołędziowska 2013, 150-156.

2 Maik 2000b, 253-264; Antosik and Maik 2017, 285.

${ }^{3}$ Kostrzewski 1954, 667-676; Wróblewski 1954, 677-698; Nahlik 1956, 519-540; Wróblewski 1958, 61-82.
}

The present paper is intended to present the current state of knowledge on early medieval looms employed in the territory of present-day Poland. The evidence consists of results of archaeological research, as well as historical, ethnographic and iconographic sources.

\section{The warp-weighted loom}

The loom of this type was the earliest and at the same time the simplest one known in this part of Europe. Its construction and technology were known in prehistory and late antiquity. The first artefacts confirming its presence in Europe were discovered in the Balkans, Hungary and Romania. ${ }^{4}$ Fragments of loom weights of various types, dated to the Neolithic (the second half of the $4^{\text {th }}$ - the beginning of the $3^{\text {rd }}$ millennium BC) were found, e.g. in the settlements at Szarvas 21, ${ }^{5}$ Talisz-Liga ${ }^{6}$ or Hlinsk. ${ }^{7}$ In Poland, the earliest examples of weights are also dated to the Neolithic, and they are known from settlements of the Funnel-Beaker Culture. They were also found in Książnica Wielka, Kazimierza Wielka District, in Ćmielów, Opatów District, in Pietrowice Wielkie, Racibórz District, in Polska Cerekiew-Miłowice, Kędzierzyn-Koźle District, in Tomice, Wrocław District, or in Gwoździec, Tarnów District. ${ }^{8}$

\footnotetext{
${ }^{4}$ Chmielewski 2009, 174.

${ }^{5}$ Makkay 2001, 35.

${ }^{6}$ Merkyte 2005, 109-110.

${ }^{7}$ Pavelčík 1983, 295-315.

${ }^{8}$ Chmielewski 2009, 175, Fig. 101, 105.
} 

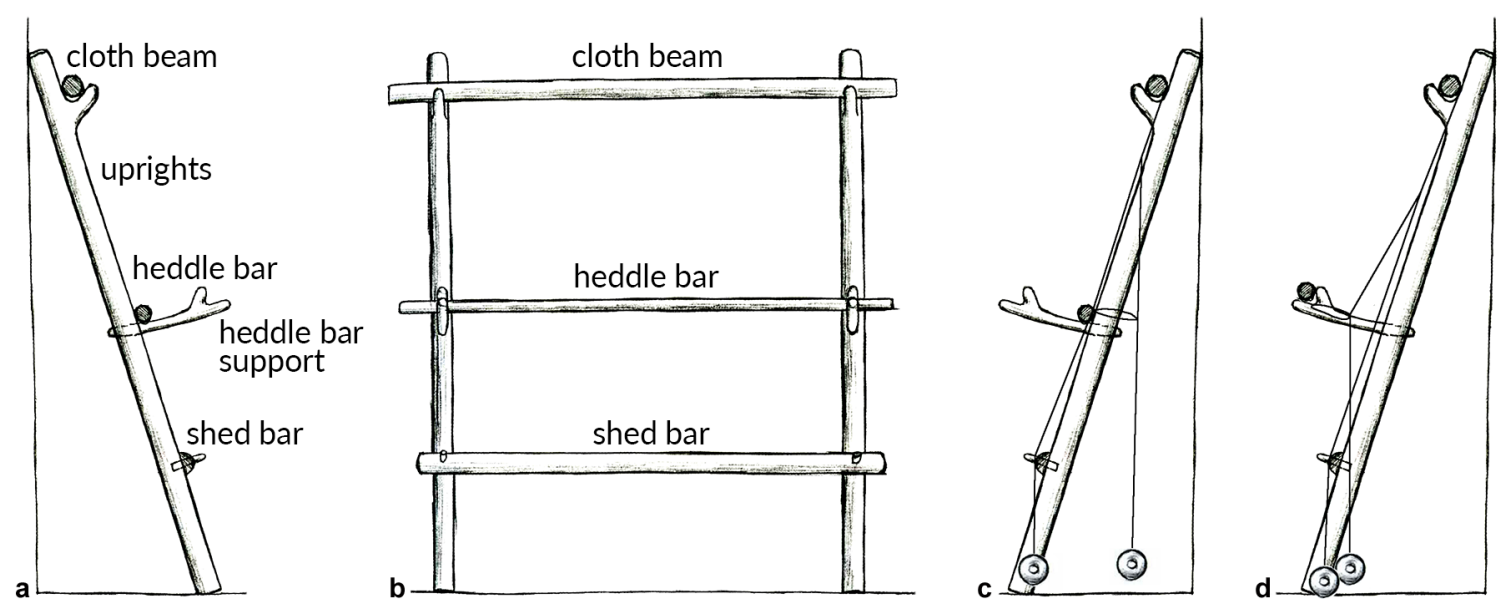

Fig. 1. a - Construction scheme of a warp-weighted loom, side view; $\mathrm{b}$ - Construction scheme of the warp-weighted loom, front view; c - Tabby weaving on a warp-weighted loom, Phase I; d - Tabby weaving on a warp-weighted loom, Phase II. After Stærmose-Nielsen 1999.

The greatest development of the warp-weighted loom, and by the same token, of textile production in the territory of Poland, is dated to the time between the Early Iron Age (700/600-450 BC) and the Roman period (0-375 AD). The construction of the warp-weighted loom underwent transformation as it was equipped with more heddles (Fig. 1). This addition permitted the production of textiles in new, more complex and impressive weaves.

An increasing significance and demand for textile production is testified to by numerous finds of loom weights from this period. They are discovered in many settlements of almost all prehistoric archaeological cultures inhabiting areas that are now Poland. Presently, more than 110 sites $^{9}$ related to the settlement of the Lusatian and Pomeranian Cultures are known, where such finds were observed as single or grouped artefacts.

Identical observations apply to discoveries of textiles. Generally, they are preserved at sepulchral sites, being most probably remains of grave clothing, shrouds or other elements decorating the body of the buried. ${ }^{10}$ These textiles are characterised by a high quality of production and strong diversity of product types, which is in particular exemplified by textiles produced by the people of the Wielbark Culture of the Roman period ${ }^{11}$. The majority of textiles were woven in twill in various variants, with the use of coloured woollen thread of the highest quality.

In reference to the period of the Early Middle Ages ( $6^{\text {th }}$ - mid- $13^{\text {th }}$ century), it can be stated that the warp-weighted loom was still in use at that time. It is evidenced by archaeological finds of loom weights ${ }^{12}$ as well as textile remains. ${ }^{13}$

${ }^{9}$ Słomska 2017.

${ }^{10}$ Słomska and Antosik, forthcoming.

${ }^{11}$ Maik 2012.

${ }^{12}$ Zimmermann 1982, 109-134; Zimmermann 1990, 418-422; Batzer and Dokkedal 1992, 231-234; Grenander Nyberg 1994a, 75-77; Pleinerová 1999, 37-44.

${ }^{13}$ Kamińska and Nahlik 1958, 85-87, 200.
An additional source of information are iconographic depictions, for instance, the depiction of a warp-weighted loom in a $13^{\text {th }}$ century manuscript in the monastery in Rein, Austria. ${ }^{14}$

The long period during which this type of loom was employed does not seem anything extraordinary if we consider that this model was still used in several regions of Scandinavia in the $20^{\text {th }}$ century. ${ }^{15}$

The use of the warp-weighted loom in textile production in Poland in the Early Middle Ages is mostly proven by loom weights found as single artefacts or groups of artefacts. However, their number is significantly lower than of those dated to the Roman period or the Early Iron Age. The largest set was found during archaeological works in the settlement in Kraków-Nowa Huta Pleszów, Kraków District, Site 18, dated to the $7^{\text {th }}$ century. ${ }^{16}$ The weights were discovered in the interior of Hut 74. They were located under one of the hut walls, as arranged in a row, one next to another. They all belonged to the same type of conical-shaped weights. In total, 162 fragments of such weights were found as well as two weights preserved in one piece. It seems that this evidence presents remains of about eight weights. Since the majority of them was subjected to intense fragmentation, not much can be said about their weight or size. Consequently, we also remain unable to reconstruct the size of the loom. Only two examples of loom weights have been preserved to the extent that permits their reconstruction. The first one was originally $10 \mathrm{~cm}$ high, its base diameter being $9 \mathrm{~cm}$ and the size of the hole $-2 \mathrm{~cm}$, and it weighted $600 \mathrm{~g}$. The second one had the same height, the diameter of $8 \mathrm{~cm}$, the hole of $1.2 \mathrm{~cm}$, and it weighed $460 \mathrm{~g}$.

\footnotetext{
${ }^{14}$ Hoffmann 1974, 261.

${ }^{15}$ Hoffmann 1974, 63-66.

${ }^{16}$ Kaczanowska 1976, 243-255.
} 
Numerous examples of loom weights were documented in the settlement dated from the end of the $8^{\text {th }}$ to mid- $10^{\text {th }}$ century in Janów Pomorski, Elbląg District ${ }^{17}$ and the settlement in Czeladź Wielka, Góra District, from the $10^{\text {th }}$ century. ${ }^{18}$ In the case of the first site, a couple or about a dozen torus-shaped weights were discovered. ${ }^{19}$ They were unearthed in the residential part of the settlement as well as its harbour part, which suggests that part of them could have been used as net weights. ${ }^{20}$ The diameter of these artefacts was between 9.5 and $16 \mathrm{~cm}$, and their thickness - between 2.5 and $7 \mathrm{~cm}$. They weighed between 350-450 g which is identical weight as in the case of the finds from York, UK (mid-late $11^{\text {th }}$ century). ${ }^{21}$ On several artefacts the presence of intentionally engraved marks was observed, most probably signifying the owner (Fig. 2). They were located on the surface of the weights ${ }^{22}$ and displayed various forms: indentations, squares or lines. ${ }^{23}$ The custom of marking weaving weights is well documented in the European evidence. An example could be provided by the artefacts from the settlements in Birka and Hedeby where as many as $12 \%$ of weights had symbols on the surface in the form of impressions. ${ }^{24}$ A single example of such an artefact is known from Břeclav-Pohansko in the Czech Republic. ${ }^{25}$

At the second of the aforementioned sites, in Czeladź Wielka, six whole and six fragmented weights were discovered in Layer II. All weights were pyramidal-shaped. They were made of clay tempered by means of an organic admixture and fired into grey-bricky colour. ${ }^{26}$ These artefacts are dated to the $5^{\text {th }} / 6^{\text {th }}$ and $7^{\text {th }}$ century. ${ }^{27}$ Unfortunately, the evidence is currently unavailable to the authors of the present text, which prevents detailed observation or measurement of the artefacts.

Yet another examples of single weights were found in several settlements, ${ }^{28}$ among others in Kraków Mogiła, Kraków District, ${ }^{29}$ in Bobięcin, Bytów District from the $2^{\text {nd }}$ half $/ 3^{\text {rd }}$ quarter of the $10^{\text {th }}$ century - end of the $11^{\text {th }}$ century, ${ }^{30}$ Zielkowo, Ilawa

${ }^{17}$ Auch et al. 2012, 99-100.

${ }^{18}$ Lodowski 1972, 124.

${ }^{19}$ The authors are of the opinion that terminology based on geometry provides the best solution for the description of loom weights. Consequently, the present paper uses terms like conical, pyramidal or torus to describe them. As far as the first two terms do not need explanation, the third one may do: torus is understood by the authors as a circular weight of oval cross-section and a hole in the centre (see Mårtensson et al. 2009, 375, Fig. 2.).

${ }^{20}$ Auch et al. 2012, 100.

${ }^{21}$ Walton Rogers 1997, 1753.

${ }^{22}$ Usually they were located at the side of walls of weights and on the top of the conical- and pyramidal-shaped weights.

${ }^{23}$ Auch et al. 2012, 184-185.

${ }^{24}$ Andersson 2003.

${ }^{25}$ Pleinerová 1999, 42, Fig. 5.

${ }^{26}$ Lodowski 1972, 124.

${ }^{27}$ Lodowski 1972, 192-193.

${ }^{28}$ Żaki 1974, 243; Parczewski 1988, 91.

${ }^{29}$ Hachulska-Ledwos 1971, 146.

${ }^{30}$ Kowalewska et al. 2012, 267.

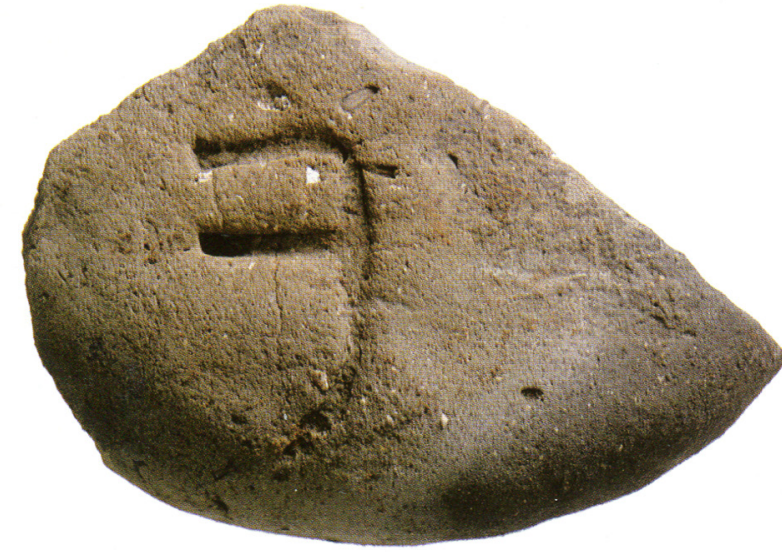

Fig. 2. Loom weight with an owner's mark from Janowo Pomorskie (Janów Pomorski), Elbląg District. After Jagodziński 2010.

District from the $11^{\text {th }}$ century ${ }^{31}$ (Fig. 3) and in the stronghold in Krzesk-Królowa Niwa, Siedlce District from the $11^{\text {th }}$ century, ${ }^{32}$ Bachórz, Rzeszów District from the $6^{\text {th }} / 7^{\text {th }}-7^{\text {th }}$ century. ${ }^{33}$ A curiosity is a chalk-made loom weight discovered in the settlement in Chełm, dated to the $13^{\text {th }}$ century. ${ }^{34}$

The presence of the vertical warp-weighted loom in the Early Middle Ages is also confirmed by fragments of textiles with preserved starting borders. The excavations brought the discovery of 5 textile fragments with borders that were produced in tablet weaving using two tablets. ${ }^{35}$ It should be, however, remembered that the starting borders are extremely rare in archaeological evidence and as such, they cannot provide a sufficient basis for further analyses.

Summing up, seven sites in total dated to the Early Middle Ages are presently known, where as many as 30-40 loom weights have been found. The majority of them are conicaland pyramidal-shaped. An exception are the aforementioned loom weights in the shape of torus from Janów Pomorski. The majority of weights from the Early Middle Ages from Poland was poorly fired and made of low quality clays. Comparing them with the weights, for example, from the sites of the Przeworsk Culture, of which 120 have been found so far, ${ }^{36}$ it is clear that in terms of quantity they are only a fraction of the earlier finds.

\section{The two-beam loom}

The presented archaeological evidence contains few but obvious testimonies of the use of the warp-weighted loom.

\footnotetext{
${ }^{31}$ Skrobot 1988, 183.

${ }^{32}$ Miśkiewiczowa 1981, 143.

${ }^{33}$ Cygan 2006, 56, 105.

${ }^{34}$ Dzieńkowski and Gołub 1999, 174.

${ }^{35}$ Kamińska and Nahlik 1958, 85-87, 200.

${ }^{36}$ Słomska 2015, 451-457.
} 


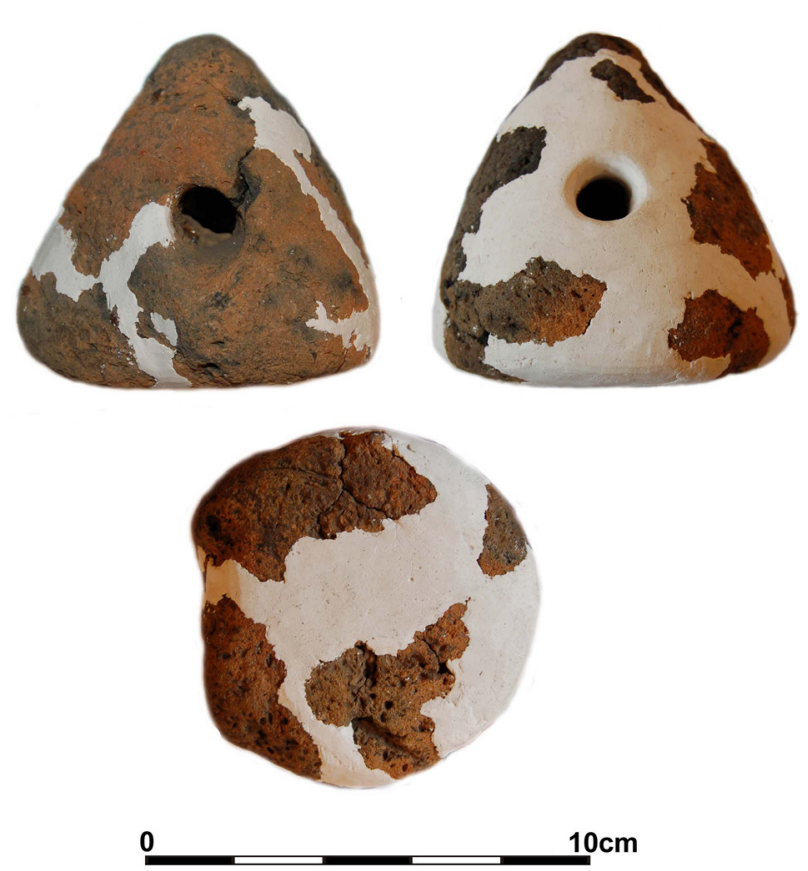

Fig. 3. Weight from Zielkowo, Iława District, Site I "Tamka". Photo Ł. Szczepański.

By contrast, the same cannot be said of the two-beam loom. Undoubtedly, it was known and employed in Europe in the Early Middle Ages and earlier. Its use is proven by iconography, e.g. such as a drawing on the tombstone of Severa Seleuciana, ${ }^{37}$ at the relief from the Forum of Nerva ${ }^{38}$ and the fresco from the Hypogeum of Aurelii in Rome. ${ }^{39}$ In all cases, the loom was depicted as ready for work, already warped.

Numerous depictions of the two-beam vertical loom are known from early medieval Europe. The earliest known picture can be found in the Utrecht Psalter, Holland, dated to the $9^{\text {th }}$ century, ${ }^{40}$ depicting many structural details of the loom, weaving tools and the process of weaving. A copy of this scene is included in another psalter from Eadwin, UK, ${ }^{41}$ dated to the $1^{\text {st }}$ half of the $12^{\text {th }}$ century. Yet another depiction of this type of loom is known from the manuscript of Rabanus Maurus from Monte Cassino, Italy, dated to the $10^{\text {th }}-11^{\text {th }}$ century. ${ }^{42}$ The warp threads are depicted here in such a manner that there is no doubt that they are prepared for the production of a tubular textile. The use of the twobeam vertical loom in the Early Middle Ages is confirmed by the discovery of remains of such a loom that belonged to the grave goods of a burial dated to the $9^{\text {th }}$ century in Oseberg, Norway (Fig. 4). ${ }^{43}$

\footnotetext{
${ }^{37}$ Stærmose-Nielsen 1999, 112, Fig. 66.A.

${ }^{38}$ Hoffmann 1974, 327.

${ }^{39}$ Stærmose-Nielsen 1999, 112, Fig. 66.C.

${ }^{40}$ Cardon 1999, 306, Fig. 119.

${ }^{41}$ Stærmose-Nielsen 1999, 113, Fig. 67.B.

${ }^{42}$ Hoffmann 1974, 329, Fig. 136.

${ }^{43}$ Hoffmann 1974, 321-333.
}

At the present moment, archaeological evidence from Poland does not include any proof of the use of this type of loom. It does not mean, however, that it could not have been employed in this area. On the contrary, we incline towards the view that this situation is a result of difficulty in interpretation of function of wooden finds. It can be also an effect of methodical errors committed in the course of excavations.

\section{The horizontal pit loom}

Consequently, the second loom type confirmed by the archaeological evidence is the horizontal pit loom. Such a loom was a transitory form between the vertical loom and the horizontal foot loom. The device consisted of a framework installed above a pit where there were pedals which were operated by a weaver who sat at the pit edge. The pedals allowed the creation of the shed by lifting and lowering the heddles. The pit loom involved the warp and weft beam mounted on sideposts. A batten was used to batten threads, or, as in the case of the discovery in Tiszalök-Rázom, Hungary, a warp beam that was attached (sewn) to the weaver's belt. In the latter case, the tension of the threads was regulated by leaning or straightening up the body during weaving. ${ }^{44}$

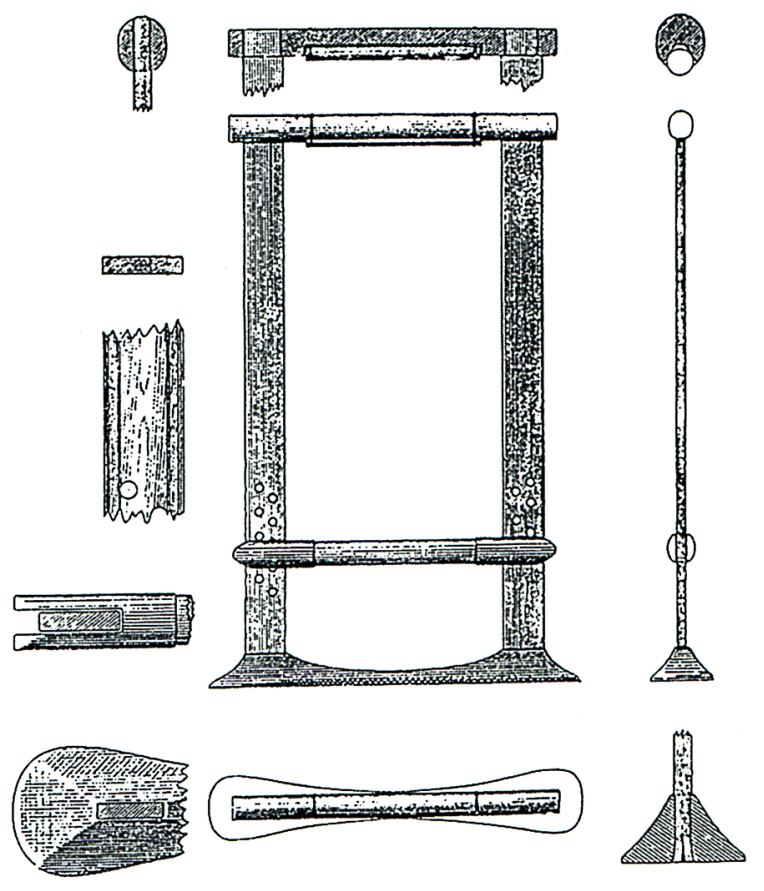

Fig. 4. Vertical two-beam loom discovered in a grave in Oseberg, $9^{\text {th }}$ century. After Cardon 1999.

${ }^{44}$ Endrei 1968, 23-29. 


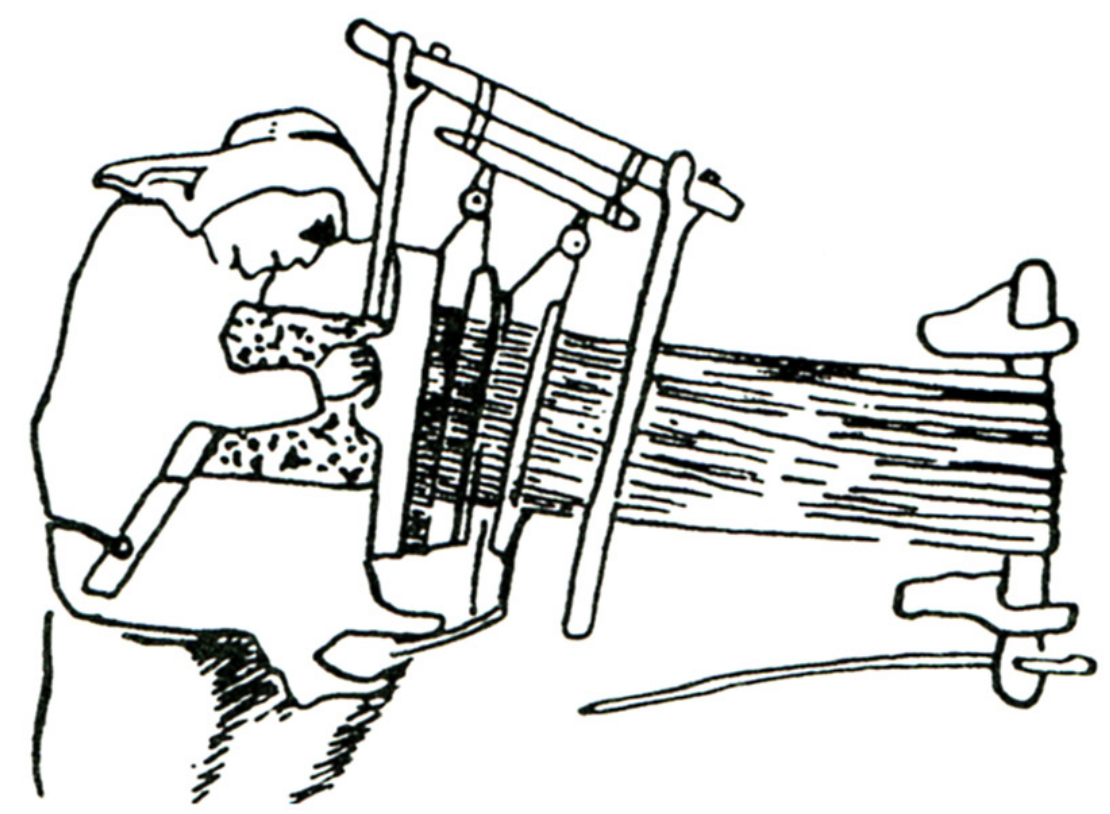

Fig. 5. Depiction of a horizontal pit loom in a Byzantine manuscript of 1386. After Endrei 1961.

In Poland, such a loom was discovered in the 1930s during excavations conducted in the stronghold in Opole-Ostrówek, Opole District. The device was found during the exploration of layers of a hut dated to the $2^{\text {nd }}$ half of the $12^{\text {th }}$ and the beginning of the $13^{\text {th }}$ century. The loom included remains of sideposts embedded in the ground, two heddle blocks and two shuttles. ${ }^{45}$ So far, it has been the only pit loom discovered in Poland. Unfortunately, the documentation of the artefact has not survived. There are no drawings, plans or photographs of the Opole discovery. Only a short mention in a text published in the journal Altschlesien of 1936 is today available. ${ }^{46}$

An analogous discovery was made in the settlement of Tiszalök-Rázom, Hungary, destroyed in 1241 during a Tatar raid. Remains of looms were identified in the ashes of two houses in this settlement. ${ }^{47} \mathrm{~A}$ series of discoveries of similar devices is also known from archaeological excavations conducted in Switzerland: Winterthur, Murten, Otelfingen, Reichenau. ${ }^{48}$ Remains of looms documented at these sites are dated to the $14^{\text {th }}$ century.

It seems that the horizontal pit loom in spite of its transitory form was employed during a long period of time. Apart from archaeological finds, it is depicted in the Book of Job, a Byzantine manuscript of 1368 (Fig. 5). ${ }^{49}$

\footnotetext{
${ }^{45}$ Sage 1936, 330-332.

${ }^{46}$ Sage $1936,330$.

${ }^{47}$ Endrei 1961, 127.

${ }^{48}$ Walton Rogers 1997, 1766.

${ }^{49}$ Endrei 1961, 132.
}

\section{The horizontal foot loom}

The last and, at the same time, the most advanced weaving device known and employed in the Early Middle Ages was the horizontal foot loom. It started to spread across Europe since the $8^{\text {th }}$ century. ${ }^{50}$ The introduction of this type of loom totally revolutionised the weaving process, speeding it up and enhancing its effectiveness. As pointed out by A. Nahlik, ${ }^{51}$ using this type of loom increased the weaver's productivity almost as many as ninefold. ${ }^{52}$ As a consequence, it led to the development of the professional weaving craft. $^{53}$

The basic foot loom was the narrow loom operated by one weaver. It should be kept in mind, though, that also wide looms operated by two weavers were in use, that enabled to weave textile that was 2.5 to $3-4$ cubits wide $(57.6 \mathrm{~cm}) .^{54}$ Such looms were depicted in Western European iconography, just to mention the stained glass windows from Bourges Cathedral, dated to 1195-1209, and from Amiens Cathedral, dated to the mid- $13^{\text {th }}$ century. ${ }^{55}$ In Poland, the earliest depiction of a wide foot loom is only dated to 1523; it can be found in St Severus' altarpiece (pentaptych) in Lubin (Lüben) in Lower Silesia. ${ }^{56}$

To date, the potential structural elements of the narrow loom and the wide loom could not be isolated in archaeological evidence. A possibility of use of such a device

\footnotetext{
${ }^{50}$ Cardon 1999, 401, Fig. 145.

${ }^{51}$ Kamińska and Nahlik 1958, 47, Fig. 13.

${ }^{52}$ Nahlik 1965, 84.

${ }^{53}$ Antosik and Maik 2017, 286.

${ }^{54}$ Kamińska and Turnau 1966, 659.

${ }^{55}$ Cardon 1999, 464, Fig. 185.

${ }^{56} \mathrm{~A}$ depiction of a fragment of the pentaptych in Lubin, after
} the title page: Kamińska and Turnau 1966. 


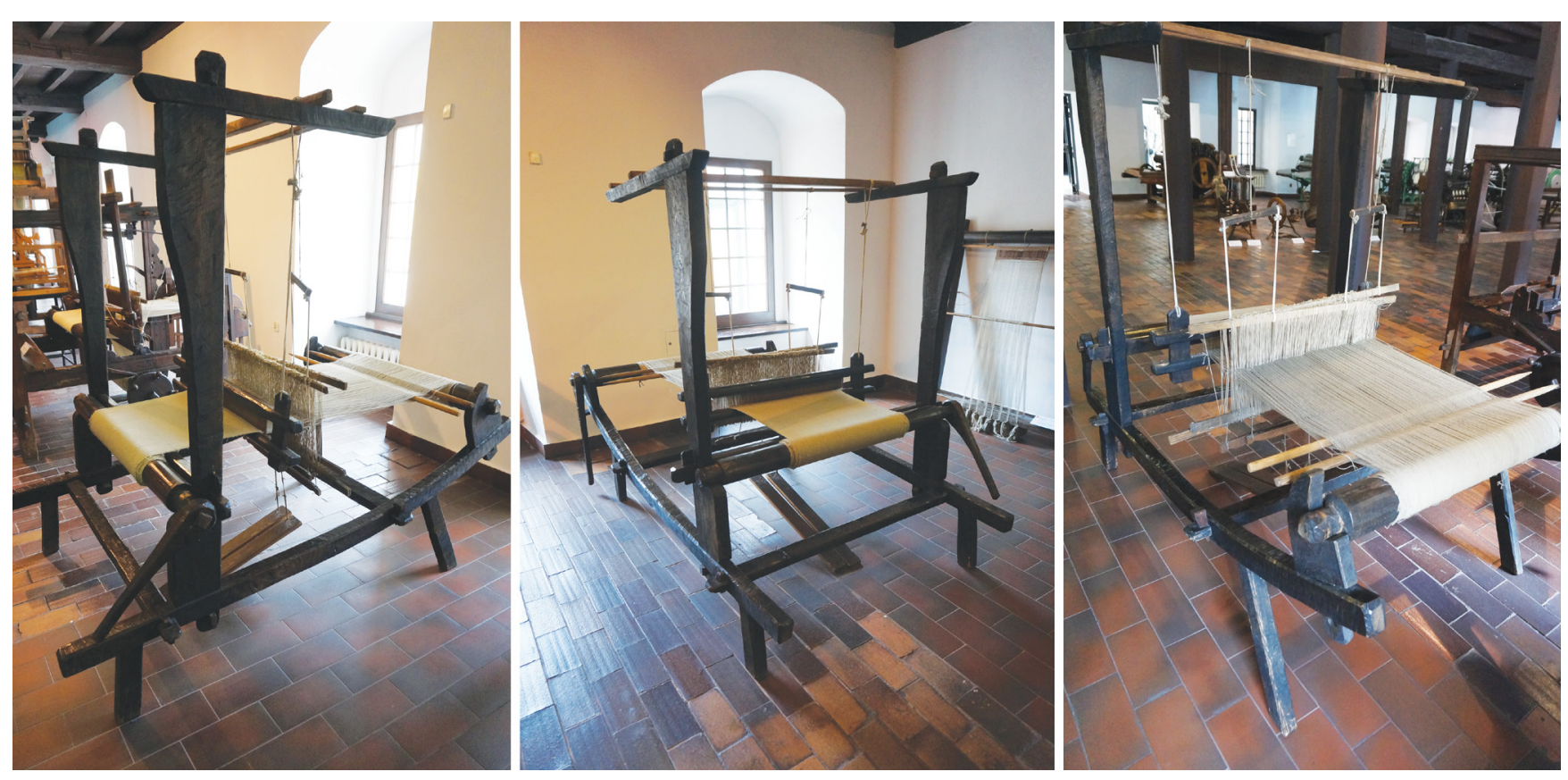

Fig. 6. Reconstruction of a horizontal treadle loom from Gdańsk by Adam Nahlik. On display in the Central Museum of Textiles in Łódź. Photo Ł. Antosik.

in the Early Middle Ages in Poland could be suggested by a fragment of $10^{\text {th }}$-century fulled textile found in the stronghold in Opole. The fabric has one border preserved and is $90 \mathrm{~cm}$ wide. However, before the fulling process, the textile was much wider, reaching $115 \mathrm{~cm}$. The observation suggests the use of the wide loom. We have to consider that it can also be an imported artefact from a western European centre of textile production. ${ }^{57}$

Remains of foot looms from Poland were found in settlement layers in Gdańsk (Site 1). The structural elements documented during excavations are dated to the last decades of the $11^{\text {th }}$ century and the $2^{\text {nd }}$ quarter of the $12^{\text {th }}$ century, based on the latest findings. ${ }^{58}$ During the exploration of Level 14 from the $1^{\text {st }}$ decade of the $12^{\text {th }}$ century, large two elements of a loom connected with a weft beam were found. ${ }^{59}$ Then, in Layer 16/17, dated to the last decade of the $11^{\text {th }}$ century, a heddle block was found. A similar discovery was made in Level 7 , dated to the $2^{\text {nd }}$ quarter of the $12^{\text {th }}$ century. ${ }^{60}$ The discovered remains were used by A. Nahlik to reconstruct the loom in drawing and then in a 1:1 model (Fig. 6). ${ }^{61}$

Fragments of the horizontal loom from the $11^{\text {th }}$ century were also found during excavations in the village of Żołte, Drawsko District (Fig. 7). At this site, in Trench 3, a wooden

${ }^{57}$ Maik 1991, 82-83.

${ }^{58}$ Kościński and Paner 2005, 11-48.

${ }^{59}$ Two fragments of a weft beam dated to the $13^{\text {th }} / 14^{\text {th }}$ century were found in Kołobrzeg: Maik 2000a, 233.

${ }^{60}$ Kamińska and Nahlik 1958, 47-48.

${ }^{61}$ The presently reconstructed loom is permanently exhibited at the Central Museum of Textiles in Łódź. artefact was found whose construction resembles the framework found in Gdańsk (Site 1). Moreover, the fragment of an oval piece of wood with one slightly concave end preserved with an oval hole and a shallow crosswise groove is interpreted as a part of the loom. Along its entire length $(25.3 \mathrm{~cm})$, the artefact displays crosswise traces of rubbing that could have been caused by wrapping thread around it. According to B. Kowalewska, the artefact could be a part of the sheaf warp from a vertical or horizontal loom. ${ }^{62}$

The fragment of a wooden artefact interpreted as a heddle was found in Layer XXXI in the Rynek Warzywny (Greengrocer's Market) in Szczecin. ${ }^{63}$ The artefact is dated to the $4^{\text {th }}-5^{\text {th }}$ decade of the $10^{\text {th }}$ century. ${ }^{64}$ Early medieval fragments of horizontal foot looms were discovered in Riga, Latvia $^{65}$ and Novgorod, Russia. ${ }^{66}$

Other discovered artefacts that could be linked to looms are heddle blocks. Such tools should have been structural elements of both horizontal pit looms and foot looms. The early medieval heddle blocks come from Opole and are dated from the $4^{\text {th }}$ quarter of the $10^{\text {th }}$ century to the $4^{\text {th }}$ quarter of the $12^{\text {th }}$ century, ${ }^{67}$ and from Wrocław, dated to the $12^{\text {th }}$ century. ${ }^{68}$ Identical archaeological finds are known from Europe, e.g. York, UK, from the $11^{\text {th }}$ century, ${ }^{69}$ Riga,

${ }^{62}$ Kowalewska 2014, 212-213.

${ }^{63}$ Kowalska 2011, 265.

${ }^{64}$ Dworaczyk and Kowalska 2011, 118-119.

${ }^{65}$ Zarina 1992, 178-186.

${ }^{66}$ Kolchin 1968.

${ }^{67}$ Bukowska-Gedigowa and Gediga 1986, 332, Table 11; 337-338, Table 15; 240, Table 17.

${ }^{68}$ Ostrowska 1957, 200, Fig. 5a.

${ }^{69}$ Walton Rogers 1997, 1766. 


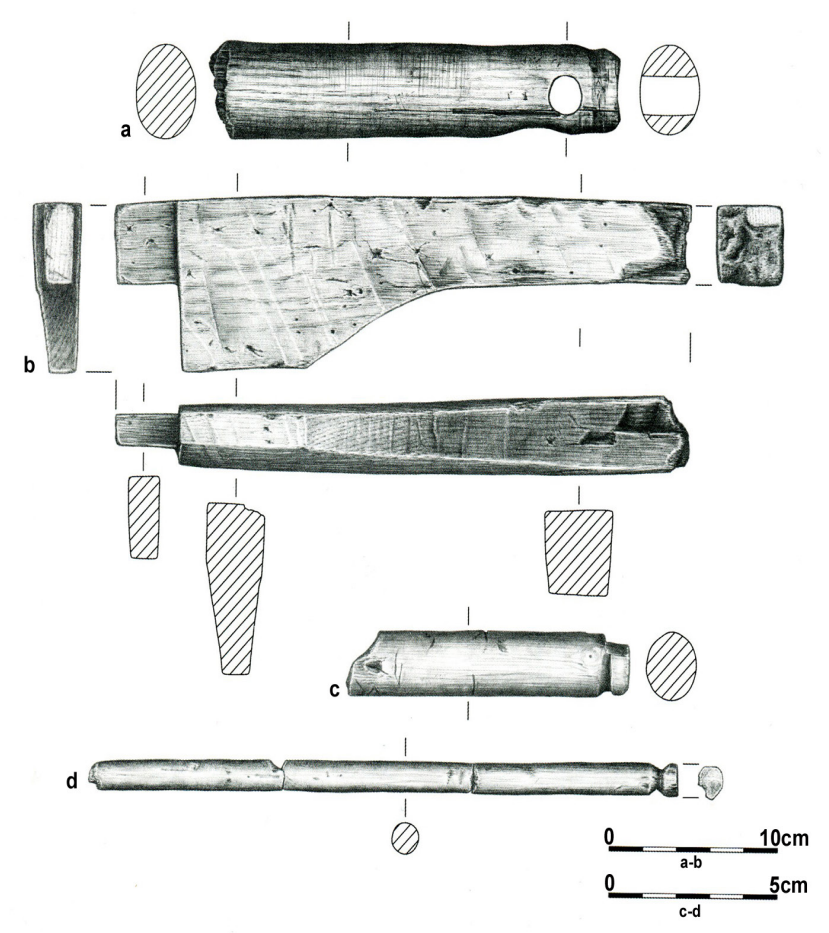

Fig. 7. Fragments of a horizontal treadle loom from the village of Żółte, Drawsko District. After Kowalewska 2014.

Latvia, from the $12^{\text {th }}-13^{\text {th }}$ century,$^{70}$ Bergen, Norway, from the $11^{\text {th }}$ century ${ }^{71}$ and Sigtuna and Lund, Sweden, from the $12^{\text {th }}$ century. ${ }^{72}$

\section{Conclusions}

As indicated by the archaeological remains of looms presented above, various types of looms were in use in the Early Middle Ages in the territory of present-day Poland. Remains of the vertical warp-weighted loom are mostly discovered at the sites dated from the $7^{\text {th }}$ to the $10^{\text {th }} / 11^{\text {th }}$ century. The remaining two types of horizontal looms, the pit loom and the foot loom are known from the archaeological exploration conducted in proto-urban and urban centres dated to the $11^{\text {th }}-13^{\text {th }}$ century. It is evident that around the turn of the $10^{\text {th }}$ century the vertical loom was replaced by the horizontal loom. Obviously, it cannot be excluded that the classical warp-weighted loom was still employed in rural areas, similarly as in northern Norway ${ }^{73}$ and in the Balkans. ${ }^{74}$ However, no direct archaeological evidence to support this theory exists, since no loom weights ${ }^{75}$ or textile borders were found.

Undoubtedly, the horizontal foot loom was the most important device used in the early medieval textile production from the $11^{\text {th }}$ century onwards. As already mentioned, the use of such loom significantly increased the weaver's productivity. From the $13^{\text {th }}-14^{\text {th }}$ century onwards, it became the basic weaving loom which was employed in the territory of Poland. The horizontal foot loom functioned without greater structural changes from the Middle Ages until J. Kay's invention of flying shuttle in $1735 .^{76}$

It is therefore justifiable to consider the Early Middle Ages as a transitory period when the old and new techniques co-existed. This fact is visible in archaeological discoveries and iconographic sources. ${ }^{77}$

\section{Bibliography}

Andersson E. 2003. Tools for Textile Production from Birka and Hedeby. Birka Studies 8. Excavations in the Black Earth 1990-1995. Stockholm.

Antosik Ł., Maik J. 2017. Późnośredniowieczne krosna tkackie w świetle środkowoeuropejskich znalezisk archeologicznych. "Archaeologia Historica Polona" 25, 285-299.

Auch M., Bogucki M., Trzeciecki M. 2012. Osadnictwo wczesnośredniowieczne na stanowisku Janów Pomorski 1. In: M. Bogucki, B. Jurkiewicz (eds.), Janów Pomorski, stan. 1. wyniki ratowniczych badań archeologicznych w latach 2007-2008, vol. 1: 2. Elbląg, 23-232.

Batzer A., Dokkedal L. 1992. The Warp-Weighted Loom: Some New Experimental Notes. In: L. Bender Jørgensen, E. Munksgaard (eds.), Archaeological Textiles in Northern Europe. Report from the $4^{\text {th }}$ NESAT Symposium, 1-5. May 1990 in Copenhagen, Tidens Tand 5. Copenhagen, 231-234.

Bukowska-Gedigowa J., Gediga B. 1986. Wczesnośredniowieczny gród na Ostrówku w Opolu. Wrocław.

Brzostowicz M. 2002. Bruszczewski zespół osadniczy we wczesnym średniowieczu. Poznań.

Cardon D. 1999. La draperie au Moyen Âge. Essor d'une grande industrie européenne. Paris.

Chudziak W. 2013. Zwiazki przędzalnictwa i tkactwa z symbolika kosmologiczna Słowian zachodnich - depozyty wodne z Jeziora Zarańskiego. In: J. Kolendo, A. Mierzwiński, S. Moździoch, L. Żygadło (eds.), Z badań nad kulturą społeczeństw

\footnotetext{
${ }^{70}$ Zarina 1992, 178-186.

${ }^{71}$ Øye 1988, 75.

${ }^{72}$ Grenander Nyberg 1994b, 205.
}

${ }^{73}$ Hoffmann 1974, 46-48.

${ }^{74}$ Moszyński 1967, 348.

${ }^{75}$ The discovered weights are net weights that could be linked to textile production, see Maik 1997, 19; Michalski 1998, 48.

${ }^{76}$ Turnau 1984, 46.

${ }^{77}$ Grenander Nyberg 1994a, 75-77; Cardon 1999. 
pradziejowych $i$ wczesnośredniowiecznych. Księga Jubileuszowa Dedykowana Profesorowi Bogusławowi Gedidze, w osiemdziesiąta rocznicę urodzin przez przyjaciót, kolegów, uczniów. Wrocław, 171-184.

Chmielewski T. J. 2009. Po nitce do kłębka... O przędzalnictwie i tkactwie młodszej epoki kamienia w Europie środkowej. Warszawa.

Cygan S. 2006. Wczesnosłowiańskie półziemianki kwadratowe na terenie Polski, Czech, Słowacji, wschodnich Niemiec i dolnej Austrii. Rzeszów.

Dominiczak-Głowacka D. 2008. Przęśliki z wczesnośredniowiecznego grodziska w Grzybowie w województwie wielkopolskim nieopodal Wrześni. "Studia Lednickie" 9, 243-270.

Dworaczyk M., Kowalska A. B. 2011. Podstawy datowania warstw kulturowych na Rynku Warzywnym. In: A. B. Kowalska, M. Dworczyk (eds.), Szczecin wczesnośredniowieczny. Nadodrzańskie centrum. Origines Polonorum 5. Warszawa, 113-152.

Dzieńkowski T., Gołub S. 1999. Czwarty sezon prac wykopaliskowych na wczesnośredniowiecznej osadzie w Chetmie. "Archeologia Polski Środkowowschodniej” 4, 171-175.

Endrei W. 1961. Der Trittwebstuhl im frühmittelalterlichen Europa. “Acta Historica” 8 (1-2), 107-136.

Endrei W. 1968. L'évolution des techniques du filage et du tissage du Moyen Âge à la révolution industrielle. Paris.

Grenander Nyberg G. 1994a. Looms for Linen. "Laborativ Arkeologi, Jurnal of Nordic Archaeological Science" 7, 75-77.

Grenander Nyberg G. 1994b. Prehistoric and Early Medieval Features in the Construction of the Oldest North-European Treadle Looms. In: G. Jaacks, K. Tidow (eds.) Archäologische Texilfunde. Archaeological Textiles: Textilsymposium Neumünster 4.-7.5. 1993, North European Symposium for Archaeological Textiles V. Neumünster, 203-212.

Hachulska-Ledwos R. 1971. Wczesnośredniowieczna osada w Nowej Hucie-Mogile. "Materiały Archeologiczne Nowej Huty" 3, 7-210.

Hoffmann M. 1974. The Warp-Weighted Loom, Second Edition. Oslo, Bergen, Tromso.

Jagodziński F. M. 2010. Truso. Między Weonodlandem a Witlandem. Elbląg.

Kaczanowska M. 1976. Sprawozdanie z badań wykopaliskowych prowadzonych w 1971 r. w Nowej Hucie na stanowisku 18 (Nowa Huta-Pleszów). "Sprawozdania Archeologiczne” 28, 243-255.

Kamińska J., Turnau I. (eds.) 1966. Zarys historii włókiennictwa na ziemiach polskich do końca XVIII wieku. Wrocław.

Kamińska J., Nahlik A. 1958. Włókiennictwo gdańskie w X-XIII wieku. Acta Archaeologica Universitatis Lodziensis 6, Łódź.

Kolchin B. A. 1968. Novogorodskiye drevnosti. Derevyannyye izdeliya. "Arkheologiya SSSR". Svod arkheologicheskikh istochnikov. Vypusk E 1-55. Moskva.

Kostrzewski J. 1954. Kiedy zjawity się Polsce krosna pionowe? "Lud” 41, 667-676.

Kościński B., Paner H. 2005. Nowe wyniki datowania grodu gdańskiego st. 1, (wykop I-V). In: H. Paner, M. Fudziński (eds.), XIV Sesja Pomorzoznawcza, vol. 2: Od wczesnego średniowiecza do czasów nowożytnych. Gdańsk, 11-48.

Kowalska A. B. 2011. Życie codzienne mieszkańców wczesnośredniowiecznego Szczecina w świetle źródeł archeologicznych. In: A. B. Kowalska, M. Dworaczyk (eds.), Szczecin wczesnośredniowieczny. Nadodrzańskie centrum. Origines Polonorum 5. Warszawa, 217-344.

Kowalewska B. 2014. Items Associated with Spinning and Weaving. In: W. Chudziak, R. Kaźmierczak (eds.), The Island in Żólte on Lake Zarańskie. Early Medieval Gateway into West Pomerania. Toruń, 196-217.

Kowalewska B., Chudziak W., Kaźmierczak R. 2012. Badania weryfikacyjno-sondażowe wczesnośredniowiecznego zespołu osadniczego w Bobięcinie, gm. Miastko (badania 2011 rok). In: E. Fudzińska (ed.), XVIII Sesja Pomorzoznawcza, vol. 1: Od epoki kamienia do wczesnego średniowiecza. Materiaty z konferencji 16-18 listopada 2011. Malbork, 257-270.

Lodowski J. 1972. Sadowel we wczesnym średniowieczu. Wrocław.

Maik J. 1991. Tekstylia wczesnośredniowieczne z wykopalisk w Opolu. Łódź, Warszawa.

Maik J. 1997. Sukiennictwo elbląskie w średniowieczu. Acta Archaeologica Lodziensia 41, Łódź.

Maik J. 2000a. Sukiennictwo kołobrzeskie w średniowieczu. In: L. Leciejewicz, M. Rębkowski (eds.), Salsa Cholbergiensis. Kołobrzeg w średniowieczu. Kołobrzeg, 233-244.

Maik J. 2000b. Średniowieczne krosno tkackie w Europie środkowej. In: Archaeologia et Historia. Księga jubileuszowa dedykowana Pani Profesor Romanie Barnycz-Gupieńcowej. Łódź, 253-264.

Maik J. 2012. Włókiennictwo kultury wielbarskiej. Łódź.

Makkay J. 2001. Textile Impressions and Related Finds of the Early Neolithic Körös Cuture in Hungary. With an Appendix: The Ritual Spinning. Budapest.

Mårtensson L., Nosch M.-L., Andersson Strand E. 2009. Shape of Things: Understanding a Loom Weight. "Oxford Journal of Archaeology" 28 (4), 373-398.

Merkyte I. 2005. Lîga. Copper Age Strategies in Bulgaria. Acta Archaeologica Supplementa 6. København.

Michalski J. 1998. Wyniki badań Starego Miasta w Ostródzie i ich wptyw na proces rewaloryzacji. In: J. Wysocki (ed.), Badania archeologiczne starych miast Warmii i Mazur a problemy ich rewaloryzacji. Materiaty z konferencji Wykno 12-14. XI. 1997 r. Nidzica, 45-51. 
Miśkiewiczowa M. 1981. Mazowsze wschodnie we wczesnym średniowieczu. Warszawa.

Moszyński K. 1967. Kultura ludowa Stowian. Warszawa.

Nahlik A. 1956. W sprawie rozwoju krosna tkackiego. "Kwartalnik Historii Kultury Materialnej” 6 (3), 519-540.

Nahlik A. 1965. Tkaniny wsi wschodnioeuropejskiej X-XIII w. Acta Archaeologica Lodziensia 13. Łódź.

Ostrowska E. 1957. Prace wykopaliskowe na Ostrowie Tumskim we Wrocławiu w 1955 r. "Sprawozdania Archeologiczne" 3, 195-203.

Øye I. 1988. Textile Equipment and Its Working Environment, Bryggen in Bergen c. 1150-1500. The Bryggen Papers. Main Series 2. Oslo.

Parczewski M. 1988. Początki kultury wczesnosłowiańskiej Polsce. Krytyka i datowanie źródeł archeologicznych. Prace Komisji Archeologicznej 27. Wrocław.

Pavelčík J. 1983. Drobné terrakoty z Hlinska u Lipniku (okr. Přerov) 2. "Památky Archeologické” 74, $295-315$.

Pleinerová I. 1999. Hliněná závaží ve slovanských objektech. "Studia Mediævalia Pragensia” 4, 37-44.

Rast-Eicher A., Windler R. 2006. „, Mit den Füssen weben“. Tradition und Innovation in der mittelalterlichen Webstuhltechnologie. "Kleidung im Mittelalter. Kunst und Architektur in der Schweiz" 57, 29-35.

Sage G. 1936. Die Gewebereste aus dem alten Oppeln. "Altschlesien” 6, 322-332.

Skrobot W. 1988. Zielkowo, gm. Lubawa, woj. olsztyńskiej. In: Informator Archeologiczny. Badania rok 1987. Warszawa, 182-183.

Słomska J. 2015. Słów kilka o krośnie pionowym w kulturze przeworskiej. In: L. Tyszler, E. Droberjar (eds.), Barbari Superiores et Inferiores. Archaeology of the Barbarians 2014. Integration Processes of the Central European Barbaricum Poland-Bohemia - Moravia - Slovakia. Łódź, Wieluń, 451-457.

Słomska J. 2017. Katalog glinianych ciężarków tkackich z epoki brąu i wczesnej epoki żelaza w kulturze tużyckiej i pomorskiej. Unpublished manuscript in the Institute of Archeology and Ethnology Polish Academy of Sciences, Łódź.

Słomska J., Antosik A. forthcoming. W jakim stroju na swój pogrzeb, czyli próba interpretacji funkcji tekstyliów archeologicznych odkrywanych w grobach z wczesnej epoki żelaza z terenu Polski. "Przegląd Archeologiczny" 66.

Stærmose-Nielsen K.-H. 1999. Kirkes vav. Opstadvaevens historie og nutidige brug. Forsøg med fortiden 6. Historisk-Arkæologisk Forsøgscenter Lejre. Lejre.

Turnau I. 1984. Moda i technika włókiennicza w Europie od XVI do XVIII wieku. Wrocław.

Walton Rogers P. 1997. Textile Production at 16-22 Coppergate. The Archaeology of York 17 (11). York.

Wróblewski T. 1954. Kilka uwag o geograficznym zasięgu występowania krosien poziomych i pionowych. "Lud” 41 (1), $677-698$.

Wróblewski T. 1958. Jeszcze o krosnach i tkactwie. "Kwartalnik Historii Kultury Materialnej” 6 (1-2), 61-82.

Zarina A. 1992. Frühe Funde von Trittwebstühlen in Letland. In: L. Bender Jørgensen, E. Munksgaard (eds.), Archaeological Textiles in Northern Europe. Report from the $4^{\text {th }}$ NESAT Symposium 1-5 May 1990 in Copenhagen. Tidens Tand 5. Copenhagen, 178-186.

Zimmermann W. H. 1982. Archäologische Befunde frühmittelalterlicher Webhäuser. Ein Beitrag zum Gewichtswebstuhl. In: L. Bender Jørgensen, K. Tidow (eds.), Textilsymposium Neumünster. Archäologische Textilfunde. Neumünster, 109-134.

Zimmermann W. H. 1990. Webhäuser im ersten und frühen zweiten Jahrtausend n. Chr. in Mittel- und Nordeuropa. In: Experimentelle Archäologie in Deutschland, Archäologische Mitteilungen aus Nordwestdeutschland 4, 418-422.

Żaki A. 1974. Archeologia Małopolski wczesnośredniowiecznej. Wrocław.

Żołędziowska I. 2013. Przęśliki. In: J. Kalaga (ed.), Sutiejsk. Gród pogranicza polsko-ruskiego z X-XIII wieku. Studium interdyscyplinarne. Warszawa, Pękowice, 150-156.

\section{Streszczenie}

\section{Wczesnośredniowieczne krosna na ziemiach polskich w świetle znalezisk archeologicznych}

W trakcie wykopaliskowych badań wczesnośredniowiecznych stanowisk datowanych na okres od VI do pierwszej połowy XIII w. archeolodzy dość często natrafiają na zabytki związane z obróbką surowców włókienniczych. Składają się na nie przede wszystkim przęśliki, wrzeciona, grzebienie oraz miecze tkackie. Zdecydowanie rzadziej odkrywane są relikty warsztatów tkackich lub choćby ich elementy konstrukcyjne. Dotychczas zgromadzone materiały pozwalają jednak stwierdzić, że w omawianym okresie na terenie ziem polskich w użyciu były trzy rodzaje krosien tkackich. Najstarsze jest krosno pionowe w typie ciężarkowym. W okresie średniowiecza mamy do czynienia ze stopniowym procesem jego zastępowania przez poziome krosno podnóżkowe, które ostatecznie weszło do powszechnego użycia.

Najstarszy typ warsztatu cechowała prostota budowy, a jego konstrukcja i zastosowane w nim rozwiązania techniczne były udoskonalane przede wszystkim w pradziejach. Nie ulega wątpliwości, że w okresie wczesnego średniowiecza wciąż 
używano krosien pionowych w typie ciężarkowym. Dowodem na to są przede wszystkim znaleziska archeologiczne w postaci ciężarków tkackich, należy jednak zauważyć, że jest ich zdecydowanie mniej niż obciążników datowanych na okres rzymski czy wczesną epokę żelaza. Stosowanie tego typu krosna potwierdzają także fragmenty tkanin z zachowanymi brzegami początkowymi. Natrafiono na nie dotychczas jedynie w trakcie badań prowadzonych na stanowisku 1 w Gdańsku, datowanym od końca XI do przełomu XII/XIII w.

W okresie wczesnego średniowiecza w Europie z całą pewnością znano i stosowano pionowe krosno dwuwałowe. Potwierdzają to przedstawienia ikonograficzne zachowane m. in. w psałterzach z Utrecht i Eadwin oraz w rękopisie Hrabana Maura z Monte Cassino. W rodzimym materiale archeologicznym nie posiadamy niestety świadectw użytkowania takiego warsztatu. Tym samym, drugim dobrze poświadczonym modelem krosna jest dopiero warsztat poziomy w typie jamowym, stanowiący formę przejściową między krosnem pionowym a podnóżkowym. Na terenie współczesnej Polski warsztat taki odkryto w latach 30. XX w. w trakcie wykopalisk prowadzonych na grodzisku w Opolu-Ostrówku. Analogiczne znaleziska znane są z materiałów europejskich m. in. z osady Tiszalök-Rázom na Węgrzech oraz ze stanowisk Winterthur, Murten, Otelfingen oraz Reichenau w Szwajcarii. Wydaje się, że warsztat poziomy w typie jamowym był w użyciu przez długi czas. Fakt ten potwierdzają nie tylko znaleziska archeologiczne, ale także wyobrażenie krosna zamieszczone w Księdze Hioba, czyli bizantyjskim manuskrypcie pochodzącym z 1368 roku.

Ostatnim i zarazem najbardziej zaawansowanym technologicznie urządzeniem tkackim stosowanym we wczesnym średniowieczu było krosno poziome w typie podnóżkowym. Zaczęło się ono rozpowszechniać na terenie Europy w VIII w. Jego pojawienie się całkowicie zrewolucjonizowało proces tkacki, przyspieszając go, a przede wszystkim zwiększając wydajność produkcji. Badania A. Nahlika dowiodły, że był to wzrost niemal dziewięciokrotny. Konsekwencją tego procesu było wykształcenie się zawodowego rzemiosła tkackiego.

Podstawowym typem krosna podnóżkowego było krosno wąskie, ale w użyciu były też warsztaty szerokie, obsługiwane przez dwie osoby. Krosna takie znane są z ikonografii zachodnioeuropejskiej, m.in. z witraży katedr w Bourges oraz w Amiens. Najstarsze wyobrażenie krosna szerokiego z terenu dzisiejszej Polski pochodzi dopiero z datowanego na rok 1523 pentaptyku św. Sewera z Lubina na Dolnym Śląsku, ale odkryte w nawarstwieniach osadniczych Gdańska, stan. 1 elementy konstrukcyjne krosien podnóżkowych - zapora do przytrzymywania wału osnowowego, część wału z czopem oraz bloczek do zawieszania nicielnic - datowane są na ostatnie dekady XI i drugą ćwierć XII w.

Na relikty krosna poziomego z XI w. natrafiono również podczas prac wykopaliskowych prowadzonych w miejscowości Żółte, pow. drawski. Znaleziony tam drewniany przedmiot swoją budową przypomina ramę odkrytą w Gdańsku. Jako element warsztatu tkackiego interpretuje się także fragment przedmiotu drewnianego z zachowanym lekko wklęsłym końcem z owalnym otworem i płytkim poprzecznym rowkiem.

Przedmiotami, które można łączyć z warsztatami tkackimi są także bloczki do zawieszania nicielnic, przy czym mogły one stanowić elementy konstrukcyjne zarówno krosien poziomych jamowych, jak i poziomych podnóżkowych. W Polsce na bloczki takie, datowane na okres wczesnego średniowiecza, natrafiono w Opolu i we Wrocławiu. Identyczne egzemplarze zarejestrowano w Rydze na Łotwie, w Bergen w Norwegii oraz w Sigtunie i Lundzie w Szwecji.

Jak wskazują archeologiczne pozostałości warsztatów tkackich, we wczesnym średniowieczu na terenie Polski występowały różne typy krosien. Pozostałości pionowego krosna ciężarkowego odkrywane są najczęściej na stanowiskach datowanych od VII do X/XI w. Dwa typy warsztatu poziomego - jamowy i podnóżkowy - znane są natomiast z badań prowadzonych w ośrodkach protomiejskich i miejskich z XI-XIII w. Na przełomie X i XI w. doszło do zastąpienia krosna pionowego warsztatami poziomymi. Zasadne jest zatem uznanie wczesnego średniowiecza za okres przejściowy, w którym współwystępowały ze sobą stare i nowe rozwiązania techniczne. Zjawisko to dotyczy także innych części Europy, co wyraźnie poświadczają zarówno odkrycia archeologiczne, jak i źródła ikonograficzne. 